\title{
Antiphospholipid antibodies in systemic sclerosis: a double oxidative hit?
}

\author{
Paul R. J. Ames
}

Received: 11 May 2009 / Accepted: 20 May 2009 /Published online: 10 June 2009

(C) Clinical Rheumatology 2009

In their paper regarding kidney function in systemic sclerosis (SSc) Wielosz et al. describe increased serum cystatin $\mathrm{C}$ and decreased glomerular filtration rate in SSc patients positive for antiphospholipid antibodies (aPL) measured as anti cardiolipin (aCL) and anti beta-2-glycoprotein I $\left(\beta_{2} \mathrm{GPI}\right)$ compared to SSc patients negative for such aPL [1]. The authors found that serum $\operatorname{IgG}$ aCL positively predicted serum cystatin $\mathrm{C}$ and negatively creatinine clearance alongside IgG $\beta_{2}$ GPI. Moreover pulmonary arterial hypertension $(\mathrm{PAH})$, proteinuria and scleroderma renal crisis were more frequent in aPL positive patients though none of the patients had clinical features of the antiphospholipid syndrome (APS) [1]. Other studies on SSc have described the occurrence of PAH more commonly in SSc patients positive for aPL [3-5] and for anti-phosphatidyl serine/prothrombin antibodies of IgM [6] and IgG isotype [7].

Altogether these are interesting data due to the interconnectedness of some vascular manifestation of SSc and the pathogenicity of aPL. Lipid peroxidation is the process through which arachidonic acid present in cell membranes and low-density lipoproteins transforms into cyclic compounds via a free radical process independent of cyclo-oxygenase. Of these cyclic compounds, 8-epiprostaglandin-F2alpha (8-epi- $\mathrm{PGF}_{2} \alpha$ ) appears to be one of the most powerful vaso-active molecules existing [8] and is able to stimulate endothelin-1 (ET-1) production in

\footnotetext{
P. R. J. Ames

Immunoclot Ltd,

Leeds, UK

P. R. J. Ames $(\bowtie)$

Department of Haematology, Royal Preston Hospital,

Preston, UK

e-mail: paxmes@aol.com
}

pulmonary vascular cells [9]. Over-generation of 8-epi$\mathrm{PGF}_{2} \alpha$ has been found in SSc [10-13] particularly in relation to $\mathrm{PAH}$ [12] the pathogenesis of which in $\mathrm{SSc}$ is strongly dependent on ET-1 [14].

The same vaso-active compounds are implicated in the pathogenesis of the antiphospholipid syndrome: aPL induces endothelial cell production of ET-1 the serum level of which was particularly elevated in patients with arterial disease [15] whereas elevated serum 8 -epi-PGF $2 \alpha$ correlated to the titre of $\mathrm{IgG}$ aCL and to diastolic blood pressure [16]. Therefore SSc and APS share some pathogenetic pathways or putting it differently the pathogenicity of aPL adds to that of SSc worsening some clinical manifestations of the latter. However, the average serum level of aCL of the current and previous articles [3-5] are below the cut-off required for the diagnosis of APS Miyakis and very few of the SSc patients in these studies had thrombosis or miscarriages [3-7] though clinical overlaps may occur [17].

This leads to two important issues related to the significance of low titre aCL and to the treatment of SSc. With regards to the first issue are low titres aCL pathogenetic or not? Leaving aside the concepts of affinity and avidity of individual aPL, these SSc/aPL studies imply that on an appropriate oxidative background low titre aPL may worsen some vascular clinical manifestations through enhanced lipid peroxidation and ET-1 production. In a similar fashion, primary APS patients who also had elevated plasma homocysteine (that associates with increased lipid peroxidation) developed thrombosis at an earlier age than those primary APS patients who had normal plasma homocysteine: the average plasma IgG aCL of the former APS patients was lower than that of the latter [19]. The threshold of 40 GPL set by the expert committee relates to the occurrence of thrombosis and miscarriage to allow a diagnosis of APS [2] but should not necessarily 
preclude assignment of any pathogenicity to aCL at a level below 40 GPL. With regards to the second issue would anti-oxidant treatment benefit SSc? A case control study of probucol in SSc, a lipid lowering agent with anti-oxidant properties, induced a significant reduction in frequency and severity of Raynaud's attacks in SSc patients who received the drug for the 12-week trial period, associated with increased resistance to oxidation of low density lipoprotein [19]. A similar study in primary APS showed significant quenching of lipid peroxidation, decreased plasma levels of ET-1, decreased thrombin generation and improvement of fibrinolysis after three weeks of probucol [20].

Given these positive effects of probucol one wonders whether it would be appropriate to consider probucol as a long-term preventative drug to retard the development of selected vascular districts involvements of SSc such as lung and kidney or as an adjuvant in the management of similar SSc manifestations alongside ET-1 receptor blockade. These answers may only come from specific trials with adequate clinical endpoints.

\section{References}

1. Wielosz E, Dryglewska, Majdan. Antiphospholipid antibodies and kidney involvement in patients with systemic sclerosis. Clin Rheumatol 2009, in press

2. Miyakis S, Lockshin MD, Atsumi T et al (2006) International consensus statement on an update of the classification criteria for definite antiphospholipid syndrome (APS). J Thromb Haemost 4:295-306

3. Marie I, Jouen F, Hellot MF, Levesque H (2008) Anticardiolipin and anti-beta2 glycoprotein I antibodies and lupus-like anticoagulant: prevalence and significance in systemic sclerosis. $\mathrm{Br} \mathrm{J}$ Dermatol 158:141-144

4. Ihn H, Sato S, Fujimoto M, Kikuchi K, Igarashi A, Soma Y et al (1996) Measurement of anticardiolipin antibodies by ELISA using $\beta_{2}$-glycoprotein I $\left(\beta_{2} \mathrm{GPI}\right)$ in systemic sclerosis. Clin Exp Immunol 105:475-479

5. Launay D, Hachulla E, Hatron PY, Michon-Pasturel U, Hebbar M, Queyrel V, Goullard L, Robin S, Rémy-Jardin M, Devulder B (2001) Pulmonary hypertension screening in systemic scleroderma: a cohort study of 67 patients. Rev Med Interne 22:819-829

6. Sanna G, Bertolaccini ML, Mameli A, Hughes GRV, Khamashta MA, Mathieu A (2005) Antiphospholipid antibodies in patients with scleroderma: prevalence and clinical significance. Ann Rheum Dis 64:1795-1796
7. Hasegawa M, Sato S, Yanaba K, Komura K, Yamazaki M, Takehara K (2004) Autoantibodies against phosphatidylserineprothrombin complex in patients with systemic sclerosis. Ann Rheum Dis 63:1514-1517

8. Roberts LJ, Morrow JD (2000) Measurement of $F_{2}$-isoprostanes as an index of oxidative stress in vivo. Free Radic Biol Med 28:505-513

9. Yi SL, Kantores C, Belcastro R, Cabacungan J, Tanswell AK, Jankov RP (2006) 8-Isoprostane-induced endothelin-1 production by infant rat pulmonary artery smooth muscle cells is mediated by Rho-kinase. Free Radic Biol Med 41:942-949

10. Stein CM, Tanner SB, Awad JA, Roberts LJ 2nd, Morrow JD (1996) Evidence of free radical-mediated injury (isoprostane overproduction) in scleroderma. Arthritis Rheum 39:1146-1150

11. Cracowski JL, Marpeau C, Carpentier PH, Imbert B, Hunt M, Stanke-Labesque F, Bessard G (2001) Enhanced in vivo lipid peroxidation in scleroderma spectrum disorders. Arthritis Rheum 44:1143-1148

12. Volpe A, Biasi D, Caramaschi P, Mantovani W, Bambara LM, Canestrini S, Ferrari M, Poli G, Degan M, Carletto A, Pieropan S, Minuz P (2006) Levels of F2-isoprostanes in systemic sclerosis: correlation with clinical features. Rheumatology 45: 314-320

13. Ogawa F, Shimizu K, Muroi E, Hara T, Hasegawa M, Takehara K, Sato S (2006) Serum levels of 8-isoprostane, a marker of oxidative stress, are elevated in patients with systemic sclerosis. Rheumatology 45:815-818

14. Mayes MD (2003) Endothelin and endothelin receptor antagonists in systemic rheumatic disease. Arthritis Rheum 48:1190-1199

15. Atsumi T, Khamashta MA, Haworth RS, Brooks G, Amengual O, Ichikawa K, Koike T, Hughes GRV (1998) Arterial disease and thrombosis in the antiphospholipid syndrome: a pathogenic role for endothelin 1. Arthritis Rheum 41:800-807

16. Ames PRJ, Nourooz-Zadeh J, Tommasino C, Alves J, Brancaccio V, Anggard EE (1998) Oxidative stress in primary antiphospholipid syndrome. Thromb Haemost 79:447-449

17. Zandman-Goddard G, Tweezer-Zaks N, Shalev T, Levy Y, Ehrenfeld M, Langevitz P (2007) A novel overlap syndrome. systemic sclerosis associated with antiphospholipid syndrome- - a case series. Ann NY Acad Sci 1108:497-504

18. Ames PRJ, Tommasino C, Iannaccone L, Brancaccio V, Margaglione M (1998) Thrombophilic genotypes in subjects with idiopathic antiphospholipid antibodies. Prevalence and significance. Thromb Haemost 79:46-49

19. Denton CP, Bunce TD, Dorado MB, Roberts Z, Wilson H, Howell K, Bruckdorfer KR, Black CM (1999) Probucol improves symptoms and reduces lipoprotein oxidation susceptibility in patients with Raynaud's phenomenon. Rheumatology 38:309-315

20. Ames PR, Tommasino C, Alves J, Morrow JD, Iannaccone L, Fossati G, Caruso S, Caccavo F, Brancaccio V (2000) Antioxidant susceptibility of pathogenic pathways in subjects with antiphospholipid antibodies: a pilot study. Lupus 9:688-695 